Published July 2019

EKONOMIKAWAN : Jurnal Ilmu Ekonomi dan Studi Pembangunan

ISSN : 1693-7600 (Print), ISSN : 2598-0157 (Online), http://jurnal.umsu.ac.Id/index.php/ekawan

\title{
Analisis Utang Luar Negeri dan Inflasi Indonesia
}

\author{
Dewi Mahrani Rangkuty ${ }^{\text {** }}$, Maya Macia Sari ${ }^{2}$ \\ ${ }^{1,2}$ Fakultas Sosial Sains Universitas Pembangunan Panca Budi Jl. Gatot Subroto No.km, \\ Simpang Tj., Kec. Medan Sunggal, Kota Medan, Sumatera Utara 20122 \\ *e-mail : dewimahrani@dosen.pancabudi.ac.id
}

\begin{abstract}
ABSTRAK
Indonesia merupakan negara sedang berkembang yang memiliki hubungan internasional bilateral maupun multilateral di pasar dunia. Dengan adanya hubungan internasional ini, Indonesia dalam meningkatkan perkembangan pembangunan dalam negeri membutuhkan modal eksternal di samping modal mandiri internal menuju laju pertumbuhan ekonomi yang tinggi demi kesejahteraan masyarakat. Penelitian ini bertujuan untuk menganalisis utang luar negeri dan inflasi Indonesia dengan time series tahun 1978-2017. Hasil penelitian dengan uji kointegrasi (cointegration test) didapatkan bahwa terjadi keseimbangan jangka panjang antara utang luar negeri dan inflasi. Dan dengan granger causality test didapatkan bahwa pada Lag 2, utang luar negeri dan inflasi Indonesia menunjukkan hubungan dua arah artinya bahwa utang luar negeri mempengaruhi inflasi Indonesia dan sebaliknya inflasi mempengaruhi utang luar negeri. Sedangkan pada Lag 4, utang luar negeri dan inflasi Indonesia menunjukkan hubungan satu arah ini berarti bahwa utang luar negeri mempengaruhi inflasi namun inflasi tidak mempengaruhi utang luar negeri selama kurun waktu penelitian. Dapat direkomendasikan kepada pemerintah Indonesia bahwa pinjaman luar negeri yang dilakukan setiap tahun sampai di waktu mendatang demi perkembangan pembangunan dan perekonomian yang lebih baik lagi tanpa membebani kas negara dan atau cadangan devisa dengan cara implementasi pinjaman luar negeri menuju lebih produktif dalam bentuk investasi pembangunan jangka panjang yang mendorong kemajuan sektor riil (pasar barang dan jasa) karena ini dapat mendorong aktivitas perekonomian domestik menuju kesejahteraan masyarakat dengan tingkat pengembalian cepat dan tinggi.
\end{abstract}

Kata kunci : utang luar negeri, inflasi 


\title{
Analysis of Indonesia's foreign debt and inflation
}

\begin{abstract}
Indonesia as developing country had international relation at world market for bilateral and multilateral. Has open trade system that international relation, Indonesia needs external capital besides independent internal capital for increase developmental domestic to high economic growth for society welfare then. This research has aimed for analyze debt service on external debt and inflation Indonesia with time series fourty period start from 1978 until 2017. The result of cointegration test showed has equilibrium relation for long term between debt service on external debt and inflation Indonesia. Then with granger causality test showed for Lag 2, debt service on external debt and inflation Indonesia showed two-way direction. It means debt service on external debt has influence inflation Indonesia and inflation has influence debt service on external debt of this research period. In recommended for government the debt service on external debt on year and or every period until the next for increasing domestic development and economy without distorted domestic fund and or exchange reserve with be more debt service on external debt productive like long term investment to push real sector progress (goods and service market) because it would be pushing domestic economy activities to society welfare with high and fast return on investment.
\end{abstract}

Keywords : external debt, inflation

\section{PENDAHULUAN}

Indonesia yang disebut juga negara dunia ketiga, menganut sistem ekonomi terbuka telah menerapkan hubungan internasional bilateral dan multilateral di pasar dunia. Sebagai negara berkembang, Indonesia berupaya melakukan perkembangan pembangunan infrastruktur dan peningkatan laju pertumbuhan ekonomi demi sebagai tujuan mensejahterakan masyarakat. Membangun negeri dan memenuhi kebutuhan masyarakatnya, Indonesia memiliki keterbatasan modal sebab dalam membiayai kebutuhan negara telah terjadi ketimpangan antara ketersediaan modal dan besarnya pengeluaran negara. Di samping modal internal mandiri dibutuhkan juga modal eksternal yang bersumber dari negara-negara sebagai mitra dagang Indonesia di pasar internasional.

Pembangunan yang berkelanjutan diperlukan untuk perbaikan ekonomi sebuah negara. Indonesia, sebagai negara sedang berkembang memiliki kendala dalam mewujudkan program-program pembangunan untuk kemakmuran nasional. Pemerintah menghadapi masalah keterbatasan modal untuk pembiayaan pembangunan. Hal ini dikarenakan adanya kesenjangan penerimaan dan pengeluaran atau adanya defisit anggaran pembangunan. Dalam upaya mengatasi kesenjangan tersebut, Pemerintah Indonesia melakukan serangkaian kebijakan baik berupa stimulus internal maupun eksternal. Selain menggenjot sumber-sumber penerimaan negara melalui ekstensifikasi dan intensifikasi pajak dan non pajak, pemerintah Indonesia dari masa ke masa telah menerapkan kebijakan utang luar negeri dan investasi asing (Junaedi, 2018). 
Published July 2019

EKONOMIKAWAN : Jurnal Ilmu Ekonomi dan Studi Pembangunan

ISSN : 1693-7600 (Print), ISSN : 2598-0157 (Online), http://jurnal.umsu.ac.Id/index.php/ekawan

Untuk menyelenggarakan kegiatan pemerintahannya, setiap negara memerlukan anggaran atau dana yang cukup memenuhi kebutuhan agar dapat meningkatkan kesejahteraan ekonomi-sosial-budaya dan politik di dalam negerinya. Baik pada status negara maju maupun negara berkembang. Negara dunia ketiga memiliki struktur ekonomi yang masih fokus pada bidang agraris dan cenderung rentan goncangan terhadap kestabilan aktivitas ekonominya. Negara di pasar dunia memiliki hubungan internasional ekonomi kepada negara lain. Yakni arus modal masuk dan arus modal keluar, dan pinjaman dana merupakan arus modal keluar. Arus modal masuk seperti devisa, investasi, pinjaman dana. Pinjaman luar negeri disebut arus modal masuk dari luar ke dalam negeri dan memiliki konsekuensi terhadap profil APBN yang defisit, yakni apabila belanja negara atau pengeluaran agregat lebih besar daripada penerimaan. Kondisi defisit mendorong negara berkembang melakukan pinjaman luar negeri (Ningrum, 2018).

Sesuai perkembangan ekonomi global, pinjaman luar negeri menjadi sumber dana utama defisit fiskal. Sumber dana dari luar negeri selain pinjaman luar negeri dapat juga berupa investasi asing. Investasi asing juga dapat sebagai pembiayaan pembangunan dan perekonomian suatu negara. Perkembangan pinjaman luar negeri telah mengalami peningkatan yang cukup signifikan (Muhayati, 2018). Jika bicara utang luar negeri dan penanaman modal asing pada pertumbuhan ekonomi di Indonesia, tingkat inflasi juga memiliki peran dalam pertumbuhan ekonomi nasional. Harga barang-barang dan jasa secara signifikan dapat mempengaruhi aktivitas permintaan dan penawaran di pasar.

Indonesia memiliki masalah utang luar negeri yang berawal dari masa transisi pemerintahan orde lama menjadi orde baru sebab dilatarbelakangi oleh buruknya kondisi perekonomian Indonesia yakni terjadinya krisis moneter 1998 (Purwanto, 2005). Tingkat inflasi tinggi mencapai kategori hiperinflasi. Pada masa itu terjadi kelangkaan pangan, sandang, dan minim tabungan pemerintah nasional, hiperinflasi dan fluktuatifnya kurs rupiah. Harga minyak dunia juga mengalami kenaikan. Setelah itu, utang luar negeri dapat mengatasi masalah krisis ekonomi nasional. Dengan demikianleju pertumbuhan ekonomi semakin meningkat diikutii cadangan devisa yang semakin tinggi.

Utang luar negeri dibayar dengan sumber pendanaan yang berasal dari cadangan devisa, tetapi apabila cadangan devisa digunakan secara terus menerus untuk pembayaran utang luar negeri maka akan menggerus cadangan devisa nasional dan kas negara sehingga berdampak negatif terhadap sumber dana untuk pembangunan infrastruktur dalam negeri dan pertumbuhan ekonomi. Untuk meningkatkan cadangan devisa negara, pemerintah mengambil kebijakan melalui perdagangan internasional dengan meningkatkan angka net ekspor melalui hubungan ekonomi baik bilateral maupun multilateral (Juniantara, 2012).

Dengan melakukan pinjaman ke luar negeri tentu diharapkan dapat memperbaiki atau menambah nilai investasi pembangunan Indonesia. Utang luar negeri yang dilakukan setiap periode akan menambah pos pengeluaran terus menerus apabila tidak dibarengi peningkatan pada cadangan devisa. Modal pemerintah dalam pembangunan melalui utng luar negeri juga berdampak pada konsumsi agregat sehingga dapat mempengaruhi hargaharga yang ada di dalam negeri yakni terjadi inflasi. Hubungan jangka panjang dan kausalitas (timbal balik) antara utang luar negeri berdasarkan data akan dibahas dalam tulisan ini. 
Published July 2019

EKONOMIKAWAN : Jurnal Ilmu Ekonomi dan Studi Pembangunan

ISSN : $1693-7600$ (Print), ISSN : 2598-0157 (Online), http://jurnal.umsu.ac.Id/index.php/ekawan

\section{METODE PENELITIAN}

Dengan menggunakan data sekunder timeseries yang diperoleh dari website Bank Dunia (worldbank) periode 1978 sampai dengan 2017, penelitian ini menganalisis hubungan kointegrasi keseimbangan jangka panjang dan kausalitas atau timbal balik antara variabel utang luar negeri dan inflasi Indonesia.

Metode uji kointegrasi, untuk menganalisis hubungan keseimbangan antara variabel utang luar negeri dan inflasi Indonesia dalam jangka panjang. Dan uji kausalitas, untuk menganalisis hubungan timbal balik antara variabel utang luar negeri dan inflasi Indonesia dan sebaliknya.

Dari kedua metode di atas maka dari pengujiannya terhadap perilaku data timeseries dan integrasinya ini dimaksudkan sebagai uji prasyarat bagi penggunaannya. Berikut merupakan tahapan dalam pengujian kedua metode tersebut:

\section{Uji Akar Unit}

Pada tahapan ini, uji akar unit yang digunakan yakni oleh Dickey-Fuller, untuk melihat apakah data runtun waktu yang diteliti terjadi stasioneritas atau tidak yang diestimasi dengan software EViews v.10. Adapun rumus atau formula untuk uji Augmented Dickey Fuller (ADF) dinyatakan seperti di bawah ini:

$$
D_{t}=a_{0}+\gamma_{t-1}+\sum_{i=1}^{\rho} \beta_{i} D_{t-1+1}+\varepsilon_{t}
$$

Hipotesis null pada uji ini adalah $\mathrm{H}_{0}: \gamma=0$. Data dikatakan stasioneritas dengan melihat perbandingan angka statistik dari Mackinnon. Dengan kriteria penilaian jika nilai $\left|\mathrm{ADF}_{\text {stat }}\right|>$ nilai kritis Mackinnon atau nilai Prob.* t-statistic $<0,05$ disimpulkan data adalah stasioner dan jika sebaliknya disimpulkan data adalah tidak stasioner.

\section{Uji Kointegrasi}

Pada tahapan ini, uji kointegrasi untuk menganalisis kointegrasi atau hubungan keseimbangan jangka panjang antara variabel utang luar negeri dan inflasi. Metode yang digunakan adalah Johansen test. Metode ini disyaratkan melakukan dua uji statistik. Yakni, uji trace $\left(\lambda_{\text {trace }}\right)$ yang menguji Hipotesis nol dengan disyaratkan jumlah dari arah kointegrasi adalah $\leq \rho$. Berikut rumus atau formula yang digunakan:

$$
\lambda_{t} \quad(r)=-T \sum_{i=T+i}^{\rho} \text { in }(1-\lambda)
$$

Angka $\lambda_{r}+1, \ldots \lambda_{n}$ merupakan eigenvectors terkecil $(\rho-r)$. Hipotesis nol yang digunakan yakni jumlah arah kointegrasi yang sama banyaknya dengan $r$. Dan hasil vektor kointegrasi $\leq \mathrm{r}$, dimana nilai $\mathrm{r}=0,1,2$ dan seterusnya.

Selanjutnya untuk uji statistik kedua, dengan rumus atau formula seperti berikut untuk melihat angka maksimum eigenvalen $\left(\lambda_{\max }\right)$ :

$$
\lambda_{m}=(r, r+1)=-T \text { in }\left(1-\lambda_{T+1}\right)
$$

Untuk melihat terdapat atau tidak hubungan kointegrasi antar variabel utang luar negeri dan inflasi, yakni dengan melihat rasio besarnya nilai trace statistic dan max-eigen statistic dengan nilai critical value pada $\alpha=0,05$. 
Published July 2019

EKONOMIKAWAN : Jurnal Ilmu Ekonomi dan Studi Pembangunan

ISSN : 1693-7600 (Print), ISSN : 2598-0157 (Online), http://jurnal.umsu.ac.Id/index.php/ekawan

\section{Uji Kausalitas}

Pada tahapan ini, untuk melihat apakah ada hubungan satu arah, dua arah atau tidak ada hubungan sama sekali antara variabel utang luar negeri dan inflasi. Rumus atau formula yang digunakan seperti berikut:

$$
\begin{aligned}
& I_{t}=\sum_{i=1}^{m} a_{i} I_{t-i}+\sum_{j=i}^{n} b_{j} Y_{t-j}-\mu_{t} \\
& Y_{t}=\sum_{i=1}^{r} c_{i} I_{t-i}+\sum_{j=1}^{S} d_{j} Y_{t-j}-v_{t}
\end{aligned}
$$

Dimana $t$ dan $\mathrm{V}_{\mathrm{t}}$ menunjukka error terms yang mengasumsikan tidak mengandung korelasi serial, dan $\mathrm{m}=\mathrm{n}=\mathrm{r}=\mathrm{s}$. Berdasarkan hasil estimasi bentuk model persamaan (4) , (5) menghasilkan 4 kemungkinan terkait nilai koefisien regresi dari persamaanpersamaan tersebut seperti berikut:

$$
\text { [1] ji } \quad a \sum_{j=1}^{n} b_{j} \neq 0 d \quad \sum_{j=1}^{s} d_{j}=0 \text {, }
$$

Terdapat kausalitas satu arah dari variabel Y ke X.

$$
\text { [2] ji } \quad \sum_{j=1}^{n} b_{j}=0 d \quad \sum_{j=1}^{s} d_{j} \neq 0 \text {, }
$$

Terdapat kausalitas satu arah dari variabel X ke Y.

$$
\text { [3] ji } \quad \sum_{j=1}^{n} b_{j}=0 d \quad \sum_{j=1}^{s} d_{j}=0 \text {, }
$$

Tidak terdapat hubungan kausalitas antara variabel X dan Y (variabel X dan Y bebas satu sama lain).

$$
\text { [4] ji } \quad \sum_{j=1}^{n} b_{j} \neq 0 d \quad \sum_{j=1}^{s} d_{j} \neq 0
$$

Terdapat kausalitas dua arah antara variabel Ydan X.

Selanjutnya dengan memperkuat indikasi bentuk kausalitas, harus dilakukan $\mathrm{F}_{\text {test }}$ untuk setiap model regresi. 
Published July 2019

EKONOMIKAWAN : Jurnal Ilmu Ekonomi dan Studi Pembangunan

ISSN : $1693-7600$ (Print), ISSN : 2598-0157 (Online), http://jurnal.umsu.ac.Id/index.php/ekawan

\section{HASIL DAN PEMBAHASAN}

Utang luar negeri sebagai pemasukan tambahan modal dalam negeri memiliki efek positif dan negatif bagi perkembangan pembangunan dan perekonomian domestik. Ini akan menggangu kestabilan kurs rupiah terhadap dolar AS sebagai mata uang global dalam hubungan internasional. Fluktuasi kurs berdampak pada inflasi dalam negeri. Oleh sebab itu, utang beserta bunganya diharapkan tidak mengganggu kas negara dan atau cadangan devisa secara terus menerus setiap periode dengan cara meningkatkan produktivitas ekonomi pasar domestik dari penggunaan utang luar negeri tersebut sehingga tercipta industri-industri domestik mandiri.

Laju pertumbuhan utang luar negeri dan inflasi Indonesia selama 40 periode menunjukkan angka laju pertumbuhan dengan trend yang berbeda. Kebutuhan dalam negeri yang tinggi demi perkembangan pembangunan dan laju pertumbuhan ekonomi sehingga mendorong Indonesia terus melakukan pinjaman luar negeri. Pinjaman luar negeri dengan pengembalian beserta bunga dalam jangka panjang akan menggangu kas negara dan atau cadangan devisa sehingga dalam penerapannya dibutuhkan implementasi produktif terhadap pinjaman luar negeri Indonesia terutama di sektor riil (pasar barang dan jasa) yang dapat dengan segera mendorong aktivitas perekonomian dari permintaan dan penawaran barang dan jasa tersebut dan ini juga mendorong peningkatan perkembangan industri-industri domestik.

\section{Laju Pertumbuhan Utang Luar Negeri dan Inflasi Indonesia, Tahun 1978-2017}

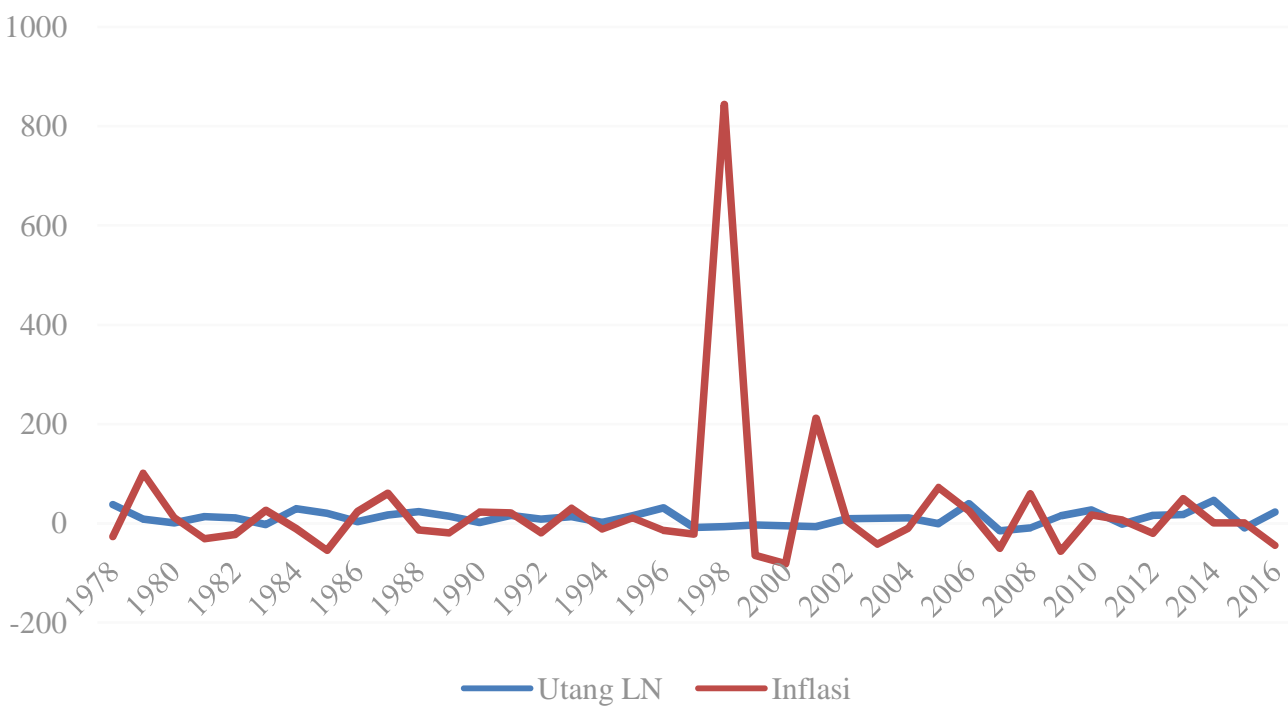

Gambar 1. Laju Pertumbuhan Utang Luar Negeri dan Inflasi Indonesia, Tahun 1978-2017

Dari Gambar di atas dapat dilihat angka laju pertumbuhan utang luar negeri menunjukkan trend yang positif sedangkan angka laju pertumbuhan inflasi Indonesia menunjukkan trend yang sangat fluktuatif selama kurun waktu 40 tahun dari 1978 sampai dengan 2017. 
Published July 2019

EKONOMIKAWAN : Jurnal Ilmu Ekonomi dan Studi Pembangunan

ISSN : $1693-7600$ (Print), ISSN : 2598-0157 (Online), http://jurnal.umsu.ac.Id/index.php/ekawan

Angka laju pertumbuhan utang luar negeri tertinggi tahun 2014 dengan angka 46,05 persen, sedangkan terendah di 2015 yakni angka negatif sebesar 9,74 persen. Trend laju pertumbuhan utang luar negeri yang positif dicerminkan bahwa Indonesia pada setiap periode ada pinjaman. Utang luar negeri yang produktif apabila dipergunakan untuk pembangunan yang bernilai investasi di masa mendatang, sehingga tingkat pengembaliannya dapat menguntungkan perekonomian negara. Trend fluktuatif laju pertumbuhan inflasi Indonesia, angka laju pertumbuhan tertinggi yakni pada taun 1998 yang terjadi hiperinflasi saat krisis moneter Indonesia sebesar 843,55 persen. Sedangkan angka laju pertumbuhan terendah yakni pada tahun 2000 sebesar negatif 81,95 persen yang mencerminkan keadaan ekonomi domestik mulai bangkit kembali pasca krisis moneter.

\section{Hasil Uji Akar Unit}

Untuk melihat data variabel utang luar negeri dan inflasi adalah stasioner atau tidak, dan membuat data menjadi stasioner dilakukan dengan ADF. Berikut hasil ADF menggunakan software EViews v.10.

Tabel 1. Hasil Augmented Dicky-Fuller, variabel Utang Luar Negeri

Null Hypothesis: EXTERN_DEBT has a unit root

Exogenous: Constant

Lag Length: 0 (Automatic - based on SIC, maxlag=7)

\begin{tabular}{|l|l|l|l|}
\hline \multicolumn{2}{|l|}{} & t-Statistic & Prob. $^{*}$ \\
\hline \multicolumn{2}{|l|}{ Augmented Dickey-Fuller test statistic } & -7.316804 & 0.0000 \\
\hline \multicolumn{1}{|l|}{ Test critical values: } & $1 \%$ level & -3.610453 & \\
& $5 \%$ level & -2.938987 & \\
& $10 \%$ level & -2.607932 & \\
\hline
\end{tabular}

*MacKinnon (1996) one-sided p-values.

Sumber: ADF test, Eviews v.10 (2019)

Tabel 2. Hasil Augmented Dicky-Fuller, variabel Inflasi

Null Hypothesis: INFLATION has a unit root

Exogenous: Constant

Lag Length: 0 (Automatic - based on SIC, maxlag=9)

\begin{tabular}{|c|c|c|c|}
\hline & t-Statistic & Prob.* \\
\hline \multicolumn{2}{|c|}{ Augmented Dickey-Fuller test statistic } & -7.113970 & 0.0000 \\
\hline Test critical values: & $\begin{array}{l}1 \% \text { level } \\
5 \% \text { level } \\
10 \% \text { level }\end{array}$ & $\begin{array}{l}-3.610453 \\
-2.938987 \\
-2.607932\end{array}$ & \\
\hline
\end{tabular}

Sumber: ADF test, Eviews v.10 (2019) 
Published July 2019

EKONOMIKAWAN : Jurnal Ilmu Ekonomi dan Studi Pembangunan

ISSN : $1693-7600$ (Print), ISSN : 2598-0157 (Online), http://jurnal.umsu.ac.Id/index.php/ekawan

Kedua variabel utang luar negeri dan inflasi adalah stasioner pada level dengan tingkat signifikansi $\alpha=5 \%$. Hal tersebut diketahui dari nilai Probabilitas $=0.0000$ (untuk Utang luar negeri) dan 0.0000 (untuk inflasi). Kedua nilai adalah lebih kecil daripada 0,05 $(\alpha=5 \%)$, yang menjelaskan bahwa kedua variabel stasioner pada derajat level.

\section{Hasil Uji Kointegrasi}

Untuk melihat apakah terdapat kointegrasi antara variabel utang luar negeri dan inflasi selama 1978 sampai dengan 2017, digunakan metode Johansen yang hasilnya dapat dilihat pada Tabel berikut:

Tabel 3. Hasil Cointegration test Metode Johansen

\begin{tabular}{|c|c|c|c|c|}
\hline \multicolumn{5}{|c|}{ Unrestricted Cointegration Rank Test (Trace) } \\
\hline $\begin{array}{l}\text { Hypothesized } \\
\text { No. of CE(s) }\end{array}$ & Eigenvalue & $\begin{array}{l}\text { Trace } \\
\text { Statistic }\end{array}$ & $\begin{array}{l}0.05 \\
\text { Critical Value }\end{array}$ & Prob.** \\
\hline None & 0.553278 & 50.32723 & 15.49471 & 0.0000 \\
\hline At most 1 & 0.404636 & 19.70615 & 3.841466 & 0.0000 \\
\hline \multicolumn{5}{|c|}{$\begin{array}{l}\text { Trace test indicates no cointegration at the } 0.05 \text { level } \\
* \text { denotes rejection of the hypothesis at the } 0.05 \text { level } \\
\text { **MacKinnon-Haug-Michelis (1999) p-values }\end{array}$} \\
\hline \multicolumn{5}{|c|}{ Unrestricted Cointegration Rank Test (Maximum Eigenvalue) } \\
\hline $\begin{array}{l}\text { Hypothesized } \\
\text { No. of CE(s) }\end{array}$ & Eigenvalue & $\begin{array}{l}\text { Trace } \\
\text { Statistic }\end{array}$ & $\begin{array}{l}0.05 \\
\text { Critical Value }\end{array}$ & Prob.** \\
\hline None & 0.553278 & 30.62108 & 14.26460 & 0.0001 \\
\hline At most 1 & 0.404636 & 19.70615 & 3.841466 & 0.0000 \\
\hline \multicolumn{5}{|c|}{$\begin{array}{l}\text { Max-eigenvalue test indicates } 2 \text { cointegrating eqn(s) at the } 0.05 \text { level } \\
* \text { denotes rejection of the hypothesis at the } 0.05 \text { level } \\
* * \text { MacKinnon-Haug-Michelis (1999) p-values }\end{array}$} \\
\hline
\end{tabular}

Sumber: data diolah, Eviews v.10 (2019)

Nilai trace statictic $>$ critical value pada $\alpha=5 \%$. Hasil tersebut ditunjukkan bahwa kedua variabel utang luar negeri dan inflasi selama 1978 sampai dengan 2017 terjadi hubungan dalam jangka panjang. Disimpulkan bahwa terdapat hubungan keseimbangan jangka panjang antara Utang luar negeri dan inflasi selama 40 tahun waktu penelitian.

\section{Hasil Uji Kusalitas}

Untuk melihat hubungan kausalitas (timbal balik) antara variabel utang luar negeri dan inflasi, digunakan metode Granger Causality yang hasilnya dapat dilihat seperti berikut: 
Published July 2019

EKONOMIKAWAN : Jurnal Ilmu Ekonomi dan Studi Pembangunan

ISSN : $1693-7600$ (Print), ISSN : 2598-0157 (Online), http://jurnal.umsu.ac.ld/index.php/ekawan

Tabel 4. Uji Granger Causality (Lag 2)

\begin{tabular}{|c|c|c|c|}
\hline $\begin{array}{l}\text { Pairwise Granger Causality Tests } \\
\text { Sample: } 19782017 \\
\text { Lags: } 2\end{array}$ & & & \\
\hline Null Hypothesis: & Obs & F-Statistic & Prob. \\
\hline $\begin{array}{l}\text { INFLATION does not Granger Cause EXTERN_DEBT } \\
\text { EXTERN_DEBT does not Granger Cause INFLATION }\end{array}$ & 38 & $\begin{array}{l}1.05045 \\
2.30529\end{array}$ & $\begin{array}{l}0.3612 \\
0.1156\end{array}$ \\
\hline
\end{tabular}

Sumber: data diolah, Eviews v.9 (2019)

Dari Tabel hasil granger causality test di atas diketahui bahwa:

1. $\mathrm{H}_{\mathrm{o}}$ : inflasi tidak mempengaruhi utang luar negeri Indonesia

$\mathrm{H}_{1}$ : inflasi mempengaruhi utang luar negeri Indonesia

2. $\mathrm{H}_{\mathrm{o}}$ : utang luar negeri tidak mempengaruhi inflasi Indonesia

$\mathrm{H}_{1}$ : utang luar negeri mempengaruhi inflasi Indonesia

Nilai probabilitas F-statistic $>\alpha=5 \%(0.3612>0.05)$ berarti $\mathrm{H}_{1}$ diterima, inflasi mempengaruhi utang luar negeri. Nilai probabilitas F-statistic $>\alpha=5 \%(0.1156>0.05)$ berarti $\mathrm{H}_{1}$ diterima, utang luar negeri mempengaruhi inflasi. Maka pada Lag 2 hasil uji kausalitas (timbal balik) menunjukkan hubungan dua arah dari inflasi dan utang luar negeri. Artinya bahwa inflasi mempengaruhi utang luar negeri dan sebaliknya utang luar negeri mempengaruhi inflasi Indonesia.

Tabel 5. Uji Granger Causality (Lag 4)

Pairwise Granger Causality Tests

Sample: 19782017

Lags: 4

\begin{tabular}{|l|l|l|l|}
\hline Null Hypothesis: & Obs & F-Statistic & Prob. \\
\hline INFLATION does not Granger Cause EXTERN_DEBT & 36 & 2.87393 & 0.0419 \\
EXTERN_DEBT does not Granger Cause INFLATION & & 1.02138 & 0.4140 \\
\hline
\end{tabular}

Sumber: data diolah, Eviews v.10 (2019)

Dari Tabel hasil granger causality test di atas diketahui bahwa:

1. $\mathrm{H}_{\mathrm{o}}$ : inflasi tidak mempengaruhi utang luar negeri

$\mathrm{H}_{1}$ : inflasi mempengaruhi utang luar negeri

2. $\mathrm{H}_{\mathrm{o}}$ : utang luar negeri tidak mempengaruhi inflasi

$\mathrm{H}_{1}$ : utang luar negeri mempengaruhi inflasi

Nilai probabilitas F-statistic $>\alpha=5 \%(0.0419<0.05)$ berarti $\mathrm{H}_{\mathrm{o}}$ diterima, inflasi tidak mempengaruhi utang luar negeri. Nilai probabilitas F-statistic $>\alpha=5 \%(0.4140>$ 0.05) berarti $\mathrm{H}_{1}$ diterima, utang luar negeri mempengaruhi inflasi Indonesia. Maka pada Lag 4 hasil uji kausalitas (timbal balik) menunjukkan hubungan satu arah, yakni utang luar negeri dan inflasi Indonesia. Artinya bahwa inflasi tidak mempengaruhi utang luar negeri akan tetapi utang luar negeri mempengaruhi inflasi. 
Published July 2019

EKONOMIKAWAN : Jurnal Ilmu Ekonomi dan Studi Pembangunan

ISSN : $1693-7600$ (Print), ISSN : 2598-0157 (Online), http://jurnal.umsu.ac.ld/index.php/ekawan

Dari hasil estimasi penelitian diketahui bahwa utang luar negeri dan inflasi Indonesia terdapat hubungan keseimbangan dalam jangka panjang. Dapat diartikan, dalam jangka panjang apabila utang luar negeri bertambah pada saat yang sama inflasi Indonesia juga bertambah begitu pula apabila angka laju pertumbuhan utang luar negeri bertambah maka pada saat yang sama diikuti dengan angka laju pertumbuhan inflasi Indonesia yang bertambah pula. Sehingga dengan keadaan ini tidak disarankan kepada Indonesia sebagai negara berkembang untuk selalu bergantung pada pinjaman luar negeri karena tidak memperkuat kondisi perekonomian domestik.

\section{SIMPULAN}

1. Laju pertumbuhan utang luar negeri Indonesia menunjukkan angka dominan positif yang berarti bahwa trend laju pertumbuhan utang luar negeri Indonesia meningkat dari tahun ke tahun selama waktu penelitian. Sedangkan untuk angka laju pertumbuhan inflasi Indonesia menunjukkan trend yang berfluktuatif.

2. Terjadi hubungan keseimbangan dalam jangka panjang antara variabel utang luar negeri dan inflasi Indonesia selama kurun waktu penelitian.

3. Pada Lag 2, utang luar negeri dan inflasi Indonesia menunjukkan hubungan dua arah. Berarti bahwa utang luar negeri mempengaruhi inflasi Indonesia dan sebaliknya inflasi mempengaruhi utang luar negeri selama 1978 sampai dengan 2017. Sedangkan pada Lag 4, utang luar negeri dan inflasi menunjukkan hubungan yang satu arah. Artinya bahwa inflasi tidak mempengaruhi variabel utang luar negeri namun utang mempengaruhi inflasi Indonesia.

\section{DAFTAR PUSTAKA}

Bank Dunia. 2019. Debt Service on External Debt and Inflation Indonesia. dari https://www.worldbank.org/ [diakses pada tanggal 02 Juni 2019].

Junaedi, Dedi. 2018. Hubungan Antara Utang Luar Negeri dengan Perekonomian dan Kemiskinan. Jurnal SNKN INAIS Bogor: Hal. 563-587

Juniantara, I.P.K. 2012. Pengaruh Ekspor Impor dan Kurs terhadap Cadangan Devisa Nasional Periode 1999-2010. Skripsi. FEB Universitas Udayana.

Muhayati, Yoga Ayu. 2018. Pengaruh Utang Luar Negeri, Penanaman Modal Asing \& Tingkat Inflasi terhadap Pertumbuhan Ekonomi di Indonesia Tahun 2000 sampai dengan 2016. Program Studi Ekonomi Pembangunan FEB Universitas Muhammadiyah Surakarta.

Ningrum, Ruwi Marta. 2018. Analisis ECM terhadap Utang Luar Negeri Indonesia Tahun 1992 sampai dengan 2016. Ilmu Ekonomi Studi Pembangunan FEB Universitas Muhammadiyah Surakarta.

Purwanto, DA. 2005. Bisnis dan Ekonomi Politik dan Manajemen Utang Luar Negeri dalam Rangka Mendorong Pertumbuhan Ekonomi. Vol.(6) No.(1) INDEF. Jakarta.

Rangkuty, Dewi Mahrani. 2018. Analisis Ekspor Indonesia ke Jepang. Jurnal Tansiq Vol.(1) No. (2) Juli-Desember 2018: Hal. 158-168 